\title{
Cost effectiveness of complementary treatments in the United Kingdom: systematic review
}

\author{
Peter H Canter, Joanna Thompson Coon, Edzard Ernst
}

Editorial by

Thompson and

Feder

Complementary

Medicine, Peninsula

Medical School,

Universities of

Exeter and

Plymouth, Exeter

EX2 4NT

Peter H Canter

research fellow

Joanna Thompson

Coon

research fellow

Edzard Ernst

director of

complementary

medicine

Correspondence to:

P H Canter

peter.canter@

pms.acuk

BMJ 2005;331:880-1
Cost effectiveness data form a crucial part of the debate surrounding the integration of complementary treatments into the NHS. To our knowledge, studies of the cost effectiveness of complementary therapies in the United Kingdom have not previously been reviewed.

\section{Methods and results}

We systematically searched seven electronic databases and included all prospective controlled studies, done in the UK before April 2005, of the cost effectiveness of complementary treatments (see bmj.com). We excluded cost minimisation studies because complementary treatments are insufficiently tested in the NHS to warrant the assumption that they are as effective as conventional treatments. Five studies, all randomised, were included, one of acupuncture for chronic headache and four of spinal manipulation for different types of spinal pain (table).

Acupuncture was an effective addition to usual care for chronic headache. ${ }^{1}$ Total mean costs, omitting the cost of prescription drugs in the year long study, were higher with additional acupuncture ( $£ 403 ; \$ 710 ; € 590)$ than for usual care (£217). Cost per quality adjusted life year (QALY) for acupuncture in addition to usual care was estimated as $£ 9180$.

The study by Meade et al compared individualised chiropractic spinal manipulation with Maitland mobilisation or manipulation provided by NHS outpatient clinics for back pain. ${ }^{2}$ Oswestry scores favoured chiropractic at six and 12 months and at two and three years. Direct costs of providing chiropractic and hospital based treatments in the year-long intervention were $£ 165$ and £111 per patient, respectively. More chiropractic patients subsequently sought further, uncosted, treatment for back pain.

Burton et al compared private individualised osteopathic spinal manipulation with chemonucleolysis for lumbar disc herniation. ${ }^{3}$ Both groups improved and health outcomes did not differ after a year. Annual savings per patient with manipulation, based on direct intervention costs and costs of treating therapeutic failure, were estimated as $£ 300$. Chemonucleolysis is a relatively expensive procedure, usually used when other conservative treatments have failed.

Methodological details are on bmj.com

\begin{tabular}{|c|c|c|c|c|}
\hline Modality, year & $\begin{array}{l}\text { Participants and } \\
\text { indication }\end{array}$ & Design and interventions & Results for main outcome measures & Economic analysis \\
\hline $\begin{array}{l}\text { Acupuncture, } \\
2004^{1}\end{array}$ & $\begin{array}{l}\text { Primary care patients } \\
\text { (18-65 years) } \\
\text { Chronic headache } \\
\text { mainly migraine } \\
(n=401)\end{array}$ & $\begin{array}{l}12 \text { month RCT } \\
\text { UC=usual care, } \\
\mathrm{A}=\text { usual care and acupuncture (up to } \\
\text { three sessions in three months) }\end{array}$ & $\begin{array}{l}12 \text { month headache score (patients' diaries) } \\
\text { reduced by } 34 \% \text { in } A, 16 \% \text { in UC ( } P=0.0002)\end{array}$ & $\begin{array}{l}\text { Total costs: UC } £ 217 ; \text { A } £ 403 \\
\text { NHS costs: UC £89; A £290 } \\
\text { Patient's costs: UC £129; A £114 } \\
\text { Incremental cost to NHS excluding prescriptions: £205 } \\
\text { Incremental health gain: } 0.021 \text { QALY (P=0.02). } \\
\text { Cost per QALY: £9180. }\end{array}$ \\
\hline $\begin{array}{l}\text { Manipulation, } \\
1995^{2}\end{array}$ & $\begin{array}{l}\text { Patients attending } \\
\text { hospital or } \\
\text { chiropractic clinics } \\
\text { (18-65 years) } \\
\text { Back pain }(n=741)\end{array}$ & $\begin{array}{l}12 \text { month RCT } \\
\mathrm{C}=\text { =individualised chiropractic } \\
\text { manipulation (up to } 10 \text { sessions in } 12 \\
\text { months) } \\
\mathrm{H}=\text { =individualised Maitland mobilisation } \\
\text { or manipulation by hospital staff }\end{array}$ & $\begin{array}{l}\text { Oswestry back pain questionnaire favoured } \mathrm{C} \text {; } \\
\text { mean change }(95 \% \mathrm{CI}) \text { : } \\
1.69(-0.74 \text { to } 4.12 ; \mathrm{NS} \text { ] at six weeks, } \\
3.31(0.51 \text { to } 6.11 ; \mathrm{P}<0.05) \text { at six months } \\
2.04(-0.71 \text { to } 4.79 ; \mathrm{NS}) \text { at } 12 \text { months } \\
3.02(0.08 \text { to } 5.96 ; \mathrm{P}<0.02) \text { at two years } \\
3.18(0.16 \text { to } 6.20, \mathrm{P}<0.05) \text { at three years }\end{array}$ & Direct treatment costs: C £165; H £111 \\
\hline $\begin{array}{l}\text { Manipulation, } \\
2000^{3}\end{array}$ & $\begin{array}{l}\text { Orthopaedic patients } \\
\text { (18-60 years) } \\
\text { Symptomatic lumbar } \\
\text { disc herniation } \\
(\mathrm{n}=40)\end{array}$ & $\begin{array}{l}\text { 12-month RCT } \\
\mathrm{CN}=\text { =chemonucleolysis } \\
\mathrm{M}=\text { osteopathic manipulation (variable } \\
\text { number of } 15 \text { minute sessions in } 12 \\
\text { weeks) }\end{array}$ & $\begin{array}{l}\text { Leg pain: NS at two weeks, six weeks, and } 12 \\
\text { months } \\
\text { Back pain: favoured } M \text { at two weeks and six weeks } \\
(P=\text { unreported), NS at } 12 \text { months } \\
\text { Roland disability questionnaire: favoured } M \text { at two } \\
\text { weeks ( } P=\text { =unreported), NS at six weeks and } \\
12 \text { months }\end{array}$ & $\begin{array}{l}\text { Direct treatment costs: CN } £ 800 ; \mathrm{M} £ 220 \\
\text { Estimated incremental cost of CN over M in a year } \\
\text { including cost of therapeutic failures: } £ 300 \text { a patient }\end{array}$ \\
\hline $\begin{array}{l}\text { Manipulation, } \\
2004^{4}\end{array}$ & $\begin{array}{l}\text { Primary care patients } \\
\text { (16-25 years) } \\
\text { Subacute spinal pain } \\
(\mathrm{n}=210)\end{array}$ & $\begin{array}{l}\text { Six month RCT } \\
\text { UC=usual primary care } \\
\text { M=usual primary care and osteopathic } \\
\text { spinal manipulation (three sessions) }\end{array}$ & $\begin{array}{l}\text { Extended Aberdeen spine pain scale: Favoured M } \\
\text { over UC ( } 95 \% \text { Cl } 0.7 \text { to } 9.8) \text { at two months, NS at } \\
\text { six months }\end{array}$ & $\begin{array}{l}\text { Mean healthcare costs for spinal pain for six month of } \\
\text { trial: M £129; UC £64 } \\
\text { Total mean health care costs: M } £ 328 \text {; UC } £ 307 \\
\text { Cost per QALY: M relative to UC } £ 3560\end{array}$ \\
\hline $\begin{array}{l}\text { Manipulation } \\
\text { and exercise, } \\
2004^{5}\end{array}$ & $\begin{array}{l}\text { Primary care patients } \\
\text { (18-65 years) } \\
\text { Chronic back pain } \\
(n=1334)\end{array}$ & $\begin{array}{l}12 \text { month RCT } \\
\mathrm{PC}=\text { primary care } \\
\mathrm{M}=\text { primary care and manipulation } \\
\text { (2-8 sessions in } 12 \text { weeks) } \\
\mathrm{E}=\text { primary care and exercise classes (up } \\
\text { to eight in } 4-8 \text { weeks and refresher at } \\
12 \text { weeks) } \\
\text { EM=primary care and manipulation (up } \\
\text { to eight in six weeks) and exercise } \\
\text { classes (up to eight in next six weeks } \\
\text { and refresher at } 12 \text { weeks) }\end{array}$ & $\begin{array}{l}\text { Roland Morris disability score }(95 \% \mathrm{Cl}) \text { : } \\
\mathrm{E}>\mathrm{PC} \text { at three months } 1.4 \text { (0.6 to } 2.1) \text {, NS at } 12 \\
\text { months } \\
\mathrm{M}>\mathrm{PC} \text { at three months } 1.6 \text { ( } 0.8 \text { to } 2.3) \text { and } 12 \\
\text { months } 1.0 \text { ( } 0.2 \text { to } 1.8) \\
\text { EM }>\mathrm{PC} \text { at three months } 1.9 \text { ( } 1.2 \text { to } 2.6) \text { and } 12 \\
\text { months } 1.3 \text { ( } 0.5 \text { to } 2.1)\end{array}$ & $\begin{array}{l}\text { Incremental cost relative to PC: E £140; M £195; EM } \\
£ 125 \\
\text { Cost per QALY: E dominated by EM and excluded; M } \\
\text { relative to PC £4800; M relative to EM £8700; EM } \\
\text { relative to PC £3800. }\end{array}$ \\
\hline
\end{tabular}




\section{What is already known on this topic}

The cost effectiveness of using complementary treatments in the United Kingdom has been the subject of much speculation and controversy

Rigorous cost effectiveness studies are needed

\section{What this study adds}

Cost effectiveness studies show that spinal manipulation and acupuncture represent an additional cost to usual care in the United Kingdom; estimates of cost per quality adjusted life year compare favourably with other treatments approved for use in the NHS, but it is not certain that the benefits are clinically relevant

Additional spinal manipulation in a primary care based osteopathy clinic was more effective than usual care alone for subacute spinal pain at two months but not at six months. ${ }^{4}$ Mean healthcare costs attributed to spinal pain for the six month trial were $£ 129$ for osteopathy and $£ 64$ for usual care. The authors estimated the cost as $£ 3560$ per QALY for osteopathy, but this was subject to a high random error.

The UK back pain exercise and manipulation trial compared Roland Morris disability scores after spinal manipulation, exercise classes, or manipulation followed by exercise in addition to care for chronic back pain by general practitioners. ${ }^{5}$ Exercise was superior to primary care at three months but not after a year. Manipulation and manipulation followed by exercise were significantly better than primary care at three and 12 months. Effect sizes were small to moderate. The mean incremental treatment cost relative to general practitioner care was $£ 195$ for manipulation, £140 for exercise, and $£ 125$ for combined treatment. The authors estimated the cost per QALY relative to general practitioner care as $£ 3800$ for combined treatment and $£ 4800$ for manipulation. Exercise alone was more expensive and achieved less than combined treatment.

\section{Comment}

Complementary treatments represent an additional healthcare cost in four out of the five rigorous cost effectiveness studies conducted in the UK. These studies are confined to acupuncture and spinal manipulation. Estimates of cost per QALY from three studies compare favourably with other treatments approved for use in the NHS, but for spinal manipulation the health benefits were small to moderate and are of questionable clinical significance. Measurement of costs was incomplete in all studies and omitted follow-on costs. Standard modelling methods were not used. Absence of blinding and sham control treatments may have increased non-specific treatment effects. Estimates of cost effectiveness may be less favourable in situations for which the complementary treatment is offered routinely rather than in the novel situation of a clinical trial.

Contributors: PHC conceived and designed the review. PHC and JTC analysed and interpreted the data. PHC, JTC and EE critically revised the article. All the authors drafted the article. PHC is guarantor.

Funding: No additional funding.

Competing interests: None declared.

Ethical approval: Not needed.

1 Wonderling D, Vickers AJ, Grieve R, McCarney R. Cost effectiveness analysis of a randomised trial of acupuncture for chronic headache in primary care. BMJ 2004;328:747.

2 Meade TW, Dyer S, Browne W, Frank AO. Randomised comparison of chiropractic and hospital outpatient management for low back pain: results from extended follow up. BMJ 1995;311:349-51.

3 Burton AK, Tillotson KM, Cleary J. Single-blind randomised controlled trial of chemonucleolysis and manipulation in the treatment of symptomatic lumbar disc herniation. Eur Spine J 2000;9:202-7.

4 Williams NH, Edwards RT, Linck P, Muntz R, Hibbs R, Wilkinson C, et al. Cost-utility analysis of osteopathy in primary care: results from a Cost-utility analysis of osteopathy in primary care: results from
pragmatic randomized controlled trial. Fam Pract 2004;21:643-50.

5 UK BEAM Trial Team. United Kingdom back pain exercise and manipulation (UK BEAM) randomised trial: cost effectiveness of physical treatments for back pain in primary care. BMJ 2004;329:1381.

(Accepted 5 September 2005)

doi $10.1136 /$ bmj.38625.575903.79

\section{What colour-mari are your stools?}

My mother, who had undergone endoscopy a few months earlier to investigate what thankfully turned out to be irritable bowel syndrome, caused me no end of worry when she informed me that she had black and tarry stools. I was contemplating sending her back to the gastroenterologist for a consultation, when she mentioned, in the course of the conversation, the marvellous new Italian restaurant that had just opened. Somehow a bulb flashed in my head, and I asked her, hesitantly, what she had eaten.

"Squid ink pasta," she replied, and wittered on about how hard it was to clean off her new blouse after spilling some on herself.

This brought to mind how one of our colleagues had, a few days earlier, fretted about the possibility of gastrointestinal bleeding and underlying malignancy when he, too, had passed black tarry stools. We reminded him of the huge plate of squid ink pasta he had consumed at lunch, which-in the absence of abdominal pain, loss of weight, and analgesic consumptionmade a more sinister diagnosis unlikely, especially when he had no recurrence thereafter.

These incidents caused some merriment, after which they were promptly forgotten, until a dinner recently, when two of us who shared a plate of squid ink risotto found that even half a plate of the stuff could turn our stools black and even a little tarry.

Melaena refers to black and tarry stools from the presence of altered blood, and is usually associated with upper gastrointestinal haemorrhage. The usual culprits of "pseudo-melaena" are iron tablets (which interestingly cause greenish rather than black stools), beets, liquorice, and Pepto-bismol. Squid ink is now believed to have antiretroviral and antitumour activity, but it has been popular in Italian and Asian cuisine for ages.

We feel this phenomenon is noteworthy, in that pseudo-melaena from squid ink consumption might prompt unnecessary investigations, though it would be ironic if it also prompted the discovery of lesions that might otherwise not have been investigated.

Erle C H Lim consultant neurologist (mdcelch@nus.edu.sg), Raymond C S Seet registrar, Benjamin K C Ong associate professor and head, Vernon M S Oh professor and senior consultant, Department of Medicine, National University Hospital, Singapore 